\title{
NARRATIVE FORM AND THE STRUCTURE OF MYTH
}

\author{
Emily Lyle
}

\begin{abstract}
At each stage in transmission of a tale from generation to generation, modifications take place but something remains. Thus there is a potential for material to be retained from a time in the distant past when the narrative was embedded in a total oral worldview or cosmology. This article introduces the analogical discovery method and uses it to build up a structure based on a group of tales from Greece, Ireland and Wales. It draws the conclusion that the structure of myth that is indirectly discernible through them deals with four generations, both of gods and of humans, the last of which contains the king. It agrees with the view proposed by Georges Dumézil that myth reflects human social organisation and argues in addition that matrilineal succession to kingship provides a good fit with the tales. The suggestion is put forward that there was a total, quite complex, cosmological code of which narratives retain traces and that scholars today have the opportunity of deciphering it.
\end{abstract}

Keywords: analogical discovery method; code; cosmology; gods; Indo-European; king; matrilineal succession; myth; narrative; structure mapping.

I would like to begin with a quotation from Albert Lord. He is writing about oral traditional stories and their meanings in his foreword to David E. Bynum's book The Daemon in the Wood: A Study of Oral Narrative Patterns and says (1978: xvii):

Many people ... in their thinking about tradition go no further back than two generations. To them the common phrase "handed down from generation to generation" stops with grandparents. If one does not restrict the process in that way but carries it back very literally to time immemorial, then there is a distinct possibility that the story one heard from one's grandfather might be very, very old. This is not only sound logical reasoning, it is also common sense. Not every tale told will be primeval, of course. There are late entries into the body of traditional narratives. But there is a group of narratives, probably the most significant of man's stories, which contains basic symbols of vital importance to storytellers and to their audiences since times beyond history.

I propose to look at one specific group of narratives which I think does carry us back into prehistory and even - and this point may be important - into a deeper prehistory than has been reached through the study of Indo-European languages, for there are in my view three main avenues that can lead us to an understanding of the human experience before written records: archaeology, linguistics and tra- 
ditional practices and stories. I would like to say that we should not be too tentative about our findings when we take the third of these avenues. Archaeologists and linguists quite often come up with different conclusions, and they just decide: "Oh, well, in the future we might be able to resolve these difficulties." They are not speaking always with one voice, and we also have our voice and can be saying something different and wait for the resolution in the future when we understand more fully.

Although traditional narratives may be seen as a link to prehistory, there is an immediacy about stories. The storyteller is concerned with neither the past nor the future but with the story being unfolded in his or her present. The story will have tentacles extending out into the contemporary world and internally it will be shaped into a form that is accessible to the audience and may also be adapted to fit with elements in a longer narrative in which it is embedded. How, then, can we hope to recover information about the deep past? I have already suggested the means. We often have at our disposal not just a single story but a group of stories and this allows us to study analogies. The process is not one of argument by analogy, but of discovery through analogy, which is something that has been explored recently more in the context of the sciences than of the humanities. An influential early study was "Structure-Mapping: A Theoretical Framework for Analogy" by Dedre Gentner published in Cognitive Science in 1983, and Gentner has continued to develop the concept in later work, including an article with Michael Jeziorski in the second edition of Metaphor and Thought edited by Andrew Ortony in 1993. As with metaphor, there is a source domain containing the old knowledge and the familiar and established, and the target domain where new discoveries and fresh insights are arrived at through reference to the source. The special feature of structure mapping is that whole systems are involved and it is relationships rather than objects that are seen analogically. The systems cannot be too close, or they are simply identical or nearly so, or too remote, so that they cannot be compared, but must have common elements that allow queries to be posed about the elements that differ. One clear scientific case of the success of the analogical discovery method is the role played by considering the solar system in the discovery by Rutherford of the structure of the hydrogen atom (Gentner 1983: 159-161). I have been especially interested in the point that in studying systems, the source and target are not necessarily fixed but can change places so that discoveries can happen in both of the fields.

I will turn now to the group of stories through which I arrived at what I regarded as insights that allowed me to hypothesise a structure that can be conveyed as a story which is also a myth, but is in addition a total cosmology that it will be possible to examine and test in other areas, such as the ritual year. I should explain that I have studied these stories over many years and have been implicitly using the analogical discovery method that I am now articulating and making explicit. I shall cast my discussion in a form suggested by a study of conceptual blending by Gilles Fauconnier in a book on The Analogical Mind edited by Gentner and others and published by MIT in 2001. Fauconnier says (2001: 256): 
Like standard analogical mapping, blending aligns two partial structures (the inputs). But in addition, blending projects selectively to form a third structure, the blend. The blend is not a simple composition of the inputs. Through pattern completion and dynamic elaboration, it develops an emergent organization of its own.

We have two inputs (which will in my case be stories) that can be identified as A and $B$. We require what Fauconnier refers to as two mental input spaces, that I am naming $\mathrm{A}$ and $\mathrm{B}$, and also a third space which is a more schematic frame that includes them both that he calls the generic space. There is also a fourth space, the blended space, and blending consists in projecting partially from the two input spaces into it.

As I mentioned, either of the input spaces can serve as the source (Fig. 1a), and I shall be zig-zagging about between one and the other. The two stories that will be input first are Hesiod's Theogony and the story of Lugaid of the Red Stripes from Irish historical legend and place-name lore. As Gentner notes, the first step is to select the criterion. I was struck a long time ago by the apparent importance of a wonderful birth story which told about either a multiple birth or a series of births or a single uniquely important birth of a god or man who becomes king. And so I am selecting this birth and the preceding events that lead up to it and am shedding the surrounding story in each case. The focus in the first two stories is on the kings: A Zeus, king of the gods in Greek mythology, and B Lugaid, an Irish king with a remarkable parentage. The schematic frame (Fauconnier's generic space) that embraces them both is clearly kinship and descent.

I will first build up in input space A. Each circle is a female and each triangle is a male, but it seems to me that the female, Ge, the earth, in Greek myth, may have to be seen androgynously before she gives birth to the male, and here we see the primal female pregnant with her son, who is born as Uranus, the sky (Fig. 1b). This gives us shortly two generations. In the next generation Cronus, the son of Ge and Uranus, is born, and the culminating birth of Zeus comes in the fourth generation. We have a story of royal succession with Zeus succeeding Cronus and Cronus succeeding Uranus, and the anthropologist, Mary Helms, has thrown light on a sequence like this in her book Access to Origins, when we understand the story of the gods as reflecting a human reality. She points out that a king in the pre-industrial era depended on acceptance of his rule as legitimate and that he drew his legitimacy from a connection of a supernatural kind with a source. As she analyses it, the source can be of one of two kinds. It is either a direct autochthonous connection or a second kind, that seems relevant here, that she refers to as "prior-house origins". In this, a series of ancestors is projected back from the king. What is important is the current situation and the current generation (i.e. the place of Zeus in the divine sequence). We can distinguish between this on the one hand and the predecessors on the other (Fig. 1c) and, although the story is told from start to finish of course, we should actually run it in reverse to reveal how the structure is projected backwards from the king. 

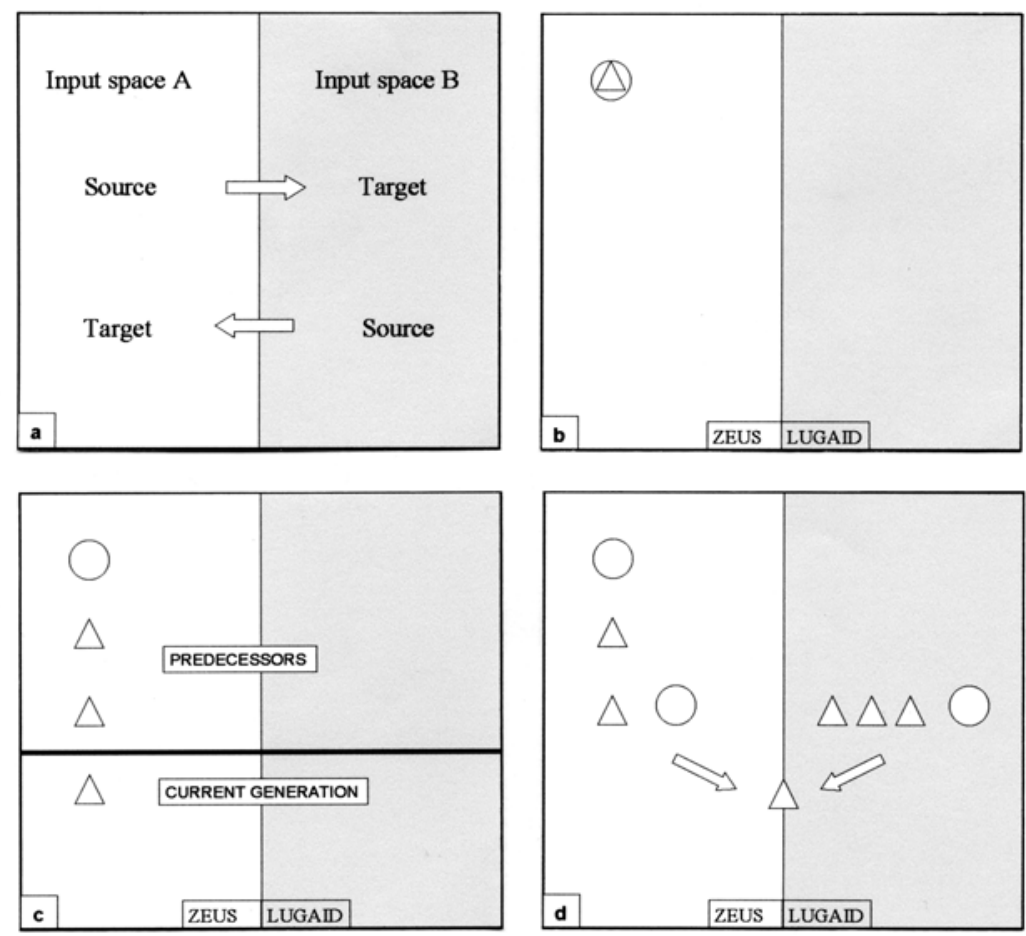

Figure 1. Illustrations introducing the application of the analogical discovery method to narratives. Drawings by the author.

I will now build up in input space B, and look at the Irish story of Lugaid. In this case Lugaid the king, who appears in the equivalent position to Zeus, is the son of a princess called Clothru. She has three brothers (i.e. the three males concerned in the story are of her own generation) and her son Lugaid was conceived when she lay one night with all three of her brothers and so he has three fathers. And here I will make an addition in input space A and show that Zeus comparably has a mother, the goddess Rhea. We now have two ways of arriving at the culminating birth of the king, which is a common factor between A and B (Fig. 1d). There is a good deal more to be said about Lugaid of the Red Stripes. Because of his three fathers, he is a threefold being and the red stripes mentioned in his name divide him into three parts as shown in Figure 2a. One stripe goes round his neck and the other is at his waist. Each of the three parts of his body is like that of the appropriate father, the head being like that of Nar, the upper body like that of Bres and the lower body like that of Lothar. This peculiar make-up of Lugaid has not gone unnoticed by previous scholarship. Georges Dumézil found him an ideal trifunctional figure, and I will pause here to outline the theory of this twentiethcentury French scholar. Dumézil argued that the Indo-Europeans had a trifunctional ideology which he realised could be related to the parts of the upright human figure among other things. The first of his three functions, which is 

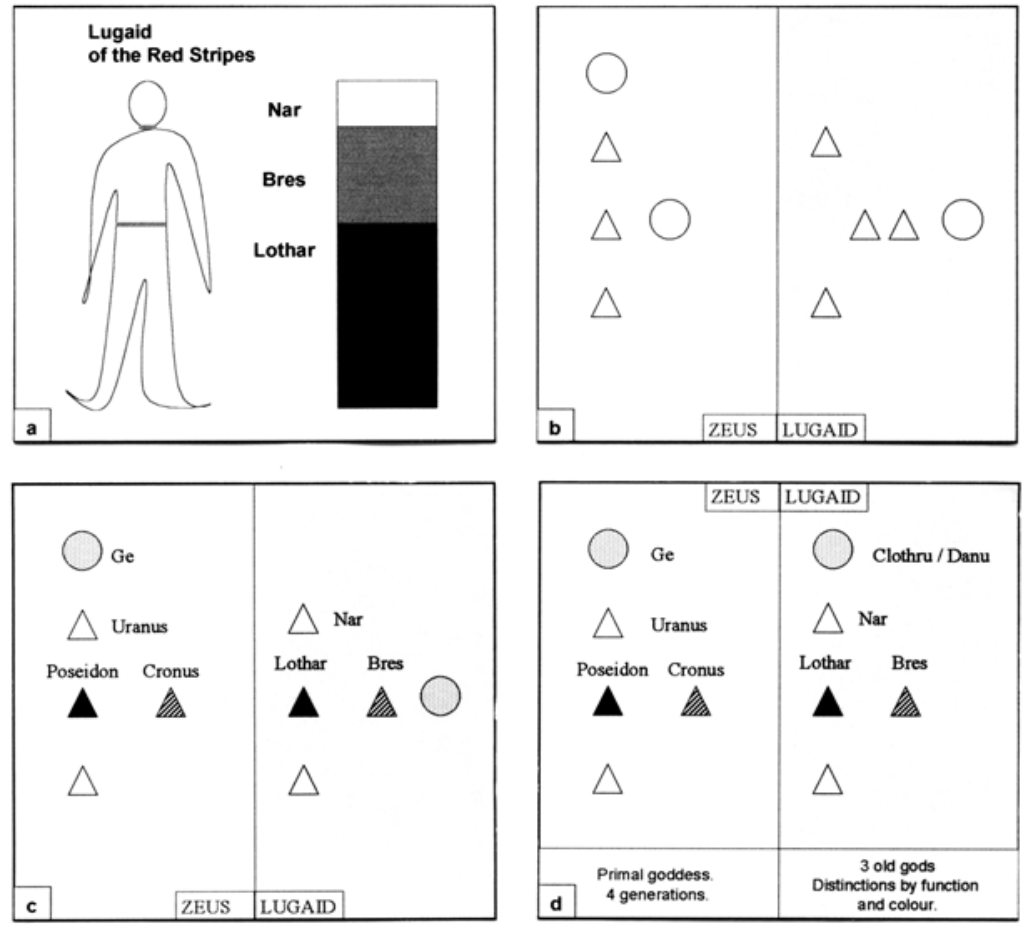

Figure 2. Illustrations of the analogical discovery method applied to birth narratives concerning Zeus and Lugaid. Drawings by the author.

the sacred, is connected with the head, the second, which is physical force, is connected with the upper body, and the third, which is prosperity and fertility, is connected with the body below the waist. The first and second functions relate also to the hierarchically superior priests and warriors and the third function to the cultivators. Rather strangely, Dumézil, who was usually highly aware of points of language, failed to observe that the names Nar, Bres and Lothar fit his theory perfectly (1973: 105), and this was noted by two later scholars, both of whom agree on the importance of Lugaid as a symbolic figure. These scholars are Bruce Lincoln, writing in Myth, Cosmos and Society (1986: 160-161), and Kim McCone, writing in Pagan Past and Christian Present in Early Irish Literature (1990: 119). They explain the names along the lines of Nar meaning noble, Bres meaning warlike, and Lothar meaning washing tub. The three males who lie with their sister and beget Lugaid are not simple equivalents but have distinctive characteristics. The separate natures of the three functions can also be expressed in terms of colour, with the first function being white, the second red and the third black.

At this point, I need to tell you about my own interpretation of the Lugaid story, which came to me as a definite eureka experience. That is, I saw something sud- 
denly in a fresh light and realised that what had seemed incomprehensible or meaningless could be a key to understanding. I had been thinking that it was impossible to connect the Lugaid story with human kinship structures, for how could a man possibly have three fathers? But then it occurred to me that I was sticking too much to the literal level, and that a man could actually have three "fathers" in inverted commas if "three fathers" is taken to mean "three important male predecessors", and that matrilineal succession can yield a pattern just like that in the Lugaid story, with two hierarchically superior males who are eligible to be kings and a third inferior male who is ineligible. Because succession is matrilineal, the king can never be the son of a king, and so his father (the Lothar of the story) is the inferior non-king in the group of three. The king can succeed his mother's brother (who I suggest is the Bres of the story) and the king before his mother's brother could have been his father's father (who I suggest is the Nar of the story). So, an interpretation of the Lugaid story called for an extension into another generation of males to give a complete run of three male generations as in the Zeus story. One male is of the grandfather generation (Fing. 2b). We can also bring colour into the picture, using the male triad of white, red and black and employing yellow as the colour of the female. It now seems as if an extra male may be needed in the Zeus half of the equation and as if the second female found there may be structurally redundant, so we can effect a switch, and can also apply colour (Fig. 2c). Since Uranus and Cronus were both rulers they can be shown as first and second function or white and red. The previously unrepresented male is the one equivalent to Lothar belonging to the below and Poseidon, the sea, seems to be the major god who does not have a place at this level in the Hesiod story and so can be added here (but without any implication that the Greek story as known to us ever included him in this role). The possibility is that aspects of Poseidon in other contexts may be illuminated by this placement of him. We can also include the Irish male names already discussed in input space B. Clothru herself appears in this story as sister only but, if we see her as structurally a primal goddess like Ge, we can identify her with the Irish goddess who appears under the names of Boand and Danu (Fig. 2d).

I have been zig-zagging back and forward between the two input spaces, as I said I would, using each as source and each as target. The Zeus half has been source for the primal goddess and the four generation sequence that she begins, and the Lugaid half has been source for the need for three old gods, not simply two, and for our ability to distinguish them by function and colour. The blend we arrive at can be shown as in Figure 3a. Since the king embodies all three functions, no single colour is representative of him.

We can place the structure of our first blend now in input space A and introduce a new story in input space B (Fig. 3b). This is the story of the birth of the god Horus (or Aroueris as he is called) in Plutarch's Of Isis and Osiris which contains a mixture of Greek and Egyptian ideas. The commentator (Griffiths 1970: 291) finds the fact that the female of the story has three consorts "problematic" but coming to the Horus story, as we do, after the Lugaid story, this curious feature is what we have begun to expect. The short account in Plutarch tells how it comes about that the young Horus is born, along with four siblings, on the five extra 

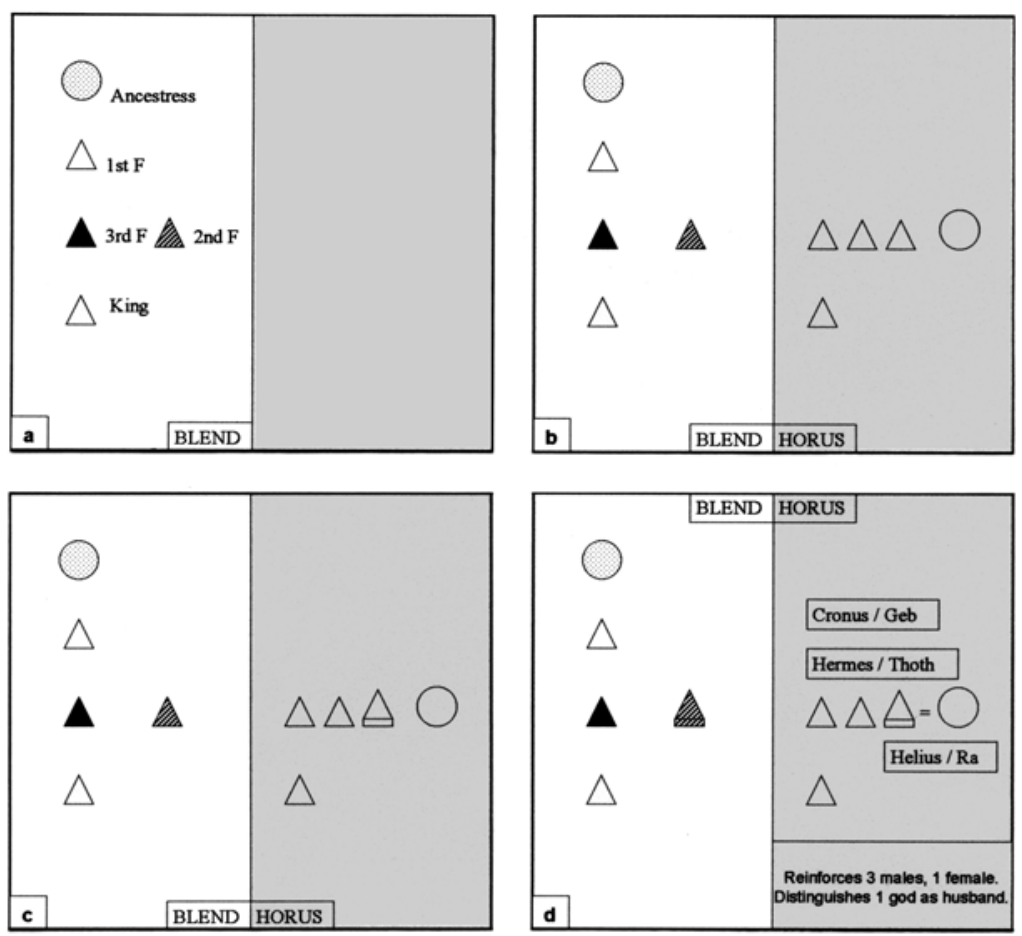

Figure 3. Illustrations of the analogical discovery method applied to a blended structure and a birth narrative concerning Horus. Drawings by the author.

days outside the twelve 30-day months of the Egyptian calendar. The story is different from the one in Hesiod's Theogony, although some of the names are the same. Here Cronus is the lover not the husband of Rhea. It is Helius who is the husband figure, who tries in vain to keep other males away from his female. This feature allows us to distinguish one of the three gods as differing from the other pair, and I have indicated the "husband" or "preventer" by placing a bar below his triangle to add to his height (Fig. 3c). Plutarch's story runs (Griffiths 1970: 134135):

They say that when Rhea secretly had intercourse with Cronus, Helius came to know about it and set on her a curse that she should not give birth in any month or year. Then Hermes, falling in love with the goddess, became intimate with her, and then played draughts against the Moon. He won the seventieth part of each of her illuminations, and having put together five days out of the whole of his gains, he added them to the three hundred and sixty; these five the Egyptians now call the epagomenal days and on them they celebrate the gods' birthdays. 
Plutarch adds: "They say that Osiris and Aroueris [i.e. Horus] were the offspring of Helius, Isis of Hermes, and Typhon [i.e. Seth] and Nephthys of Cronus." In this cosmological story, Rhea (or Nut) lies with the three gods Cronus (or Geb), Hermes (or Thoth) and Helius (or Ra), of whom Helius is the husband or preventer. The story both reinforces the structure of three males and one female, which was already present in the blend, and also adds the possibility of distinguishing one male of the three as having a special relationship with the female differing from that of the other two and filling a role definable as husband or preventer, though it should be noted, I suppose, that the attempt at prevention fails. Looking back at the components of the blend, we find that the Cronus of the Theogony was the husband of Rhea and accordingly the red triangle can now be shown raised in the same way as the triangle indicating Helius in the Horus story (Fig. 3d). The correspondence is not confined to the fact that Cronus is the husband; he also, like Helius, is a failed preventer. Helius in the Horus story tries to prevent his wife (a) having intercourse with another male, and (b) bearing children, but she tricks him and bears children who have three fathers. Cronus in the Zeus story tries to prevent his wife giving birth to children who will live by swallowing them at birth, but she tricks him and Zeus survives. The blend now appears as in Figure 4a.

A story of three gods lying with the one goddess also occurs in Old Norse mythology where the husband is Odin, and Karen Bek-Pedersen has included discussion of this in her study of Balder in the papers arising from the 2004 Lund conference on Old Norse Religion (Bek-Pedersen 2006). I will turn now to a Welsh story that she also treats, which concerns the birth of Lleu. Lleu is held to be a cognate of the well-known and centrally important Irish god, Lug, and Lugaid (as in Lugaid of the Red Stripes) is considered a form of the name Lug, so we seem to have a Celtic complex here.

The story of the birth of Lleu occurs in the Fourth Branch of the Mabinogi, which is full of magical happenings, from which I shall elicit the main threads that concern us (Jones and Jones, tr., 1949: 55-64). There are three males in two generations: Math, the older man, and Gilfaethwy and Gwydion, who are the sons of his sister Don. In this case Math is the preventer, indicated by the raised red triangle (Fig. 4b). He tries in vain to prevent sexual access to a young virgin called Goewin, but Gilfaethwy and Gwydion acting together circumvent him and Gilfaethwy rapes her. Later in the story, the virginity of a young woman called Aranrhod is tested and found wanting when she gives birth to two sons, one of whom is Lleu. It seems as though the story line has been expanded and has given roles to two women, where only one would have been required in a more compact form. Another female, Math's sister Don, who is mentioned but plays no part in the narrative, is cognate with the Irish primal goddess Danu, and so we can suggest a revision which replaces the three females with a single one identified as the equivalent of Ge (Fig. 4c). There remains the point that Lleu has a twin, Dylan, who is born before him and heads off shortly after birth into the sea where he swims like a fish. Looking back at the stories behind the blend, we find that Horus's negative brother Seth was part of the multiple birth in Plutarch's story, and that the king Zeus had an elder brother, Hades, who became king of the dead 

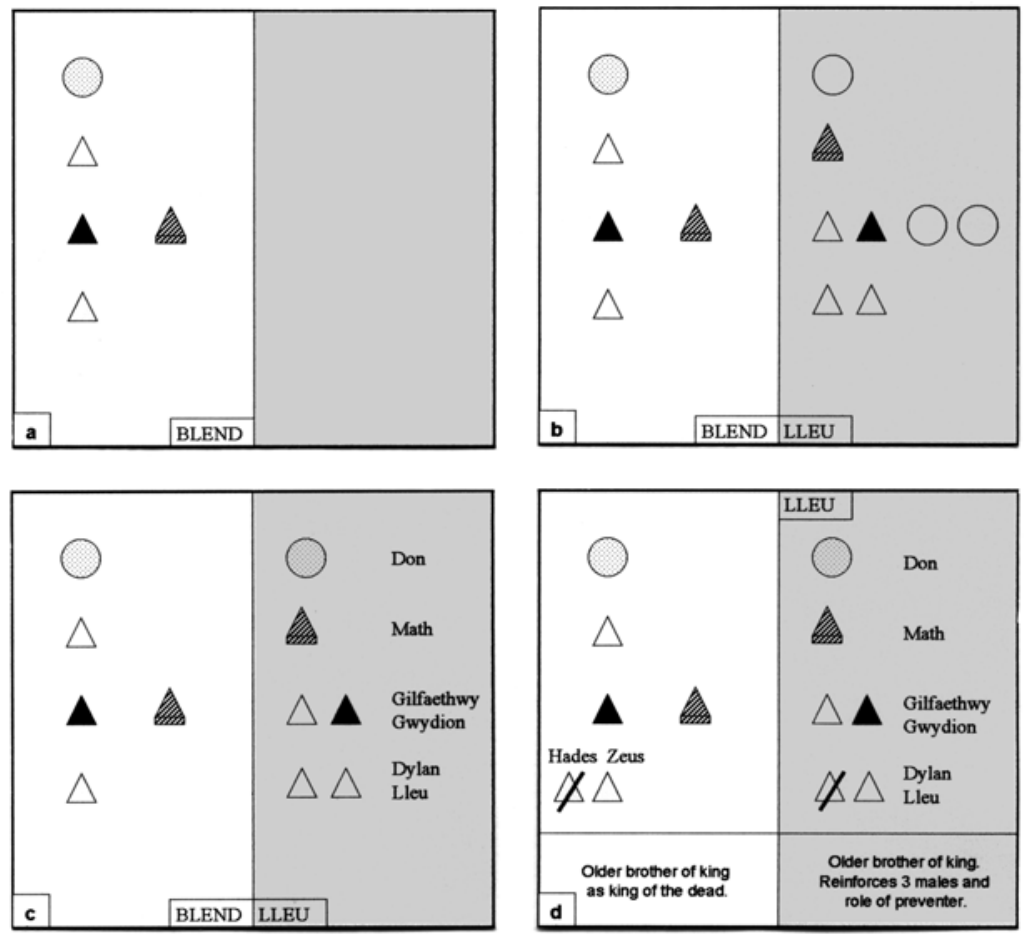

Figure 4. Illustrations of the analogical discovery method applied to a blended structure and a birth narrative concerning Lleu. Drawings by the author.

(Fig. 4d). (I should add that Hades was one of the siblings that was swallowed by Cronus; Zeus made Cronus regurgitate his brothers and sisters.) Even Dylan does not make his life among people on earth, but the Hades link identifies one of the brothers more firmly with the land of death.

The Lithuanian scholar, A. J. Greimas, speaks warmly of Dumézil's work and credits him with having broken new ground in showing that concepts of the gods were patterned after human structures. Nowadays, I would say that we need to develop the schema and its context in a number of ways. I would say, and this is a quite radical view when compared with Dumézilian orthodoxy, that the structures he identified are not exclusively Indo-European, although Indo-European stories do much to take us into a deep past. I also argue that the three functions that were tied to priests, warriors and cultivators in some times and places were more basically tied to the stages of life of wise old men (relating to the sacred), vigorous young men (relating to physical force) and wealthy mature men (relating to prosperity and fertility). That is the male side of things, but the stories I have studied today have suggested the strong presence of an ancestress (or primal goddess), from whom the kings are descended and take their eligibility. There is also another female, a young one who is a queen, and there is another set of 
twins besides the hostile ones - these are the ones known as the Ashvins in India and as the Dioskouroi, Kastor and Polydeukes, in Greece. The story is only complete when the young king wins the princess and gains her father's kingdom. Again, we are faced with a matrilineal pattern, which has been long neglected but which is being studied again by Margalit Finkelberg in Greeks and Pre-Greeks.

Greimas talked also about a code which stands in need of decipherment (1992: 3). The theory that many of our mythological narratives are patterned after matrilineal succession to kingship may be one of the ways to break the code and read more clearly messages that have had meaning at all times whenever these stories were told but were initially shaped, and had their earliest meaning, at a period before history. The first step in the breaking of a code is the recognition that there may be a code there to be broken. The recent huge discovery in this area - it has been very exciting within our own time - has been the breaking of the Maya code, which turned out to be fully linguistic in a way that for many, many years had just been assumed to be impossible (Coe 1992). It was someone taking the possibility seriously that eventually allowed that code to be broken. The code that I am suggesting underlies our general old-world patterns is not as complex as a linguistic one - I am not implying that we have a language code here. We have something, though, that is quite complex, and is much more complex than the simple formulation by Dumézil, who led us in quite the wrong direction in some respects, though being responsible for the important recognition of a structure based on human social organisation which can now be refined.

I would like to conclude by sketching in some additional story material from Greece that may add to our awareness of the place of matrilineal succession in myth and legend. The Dioskouroi, Kastor and Polydeukes, were the brothers of Helen of Troy, and their story is one that could usefully be studied by the analogical discovery method I have used today, with parallels from a variety of sources including the Indian epics, the Mahabharata and the Ramayana (cf. Ward 1968; West 1975; Winn 1995: ch. 6). They start life together in an egg, for Zeus came to their mother Leda in the shape of a swan. The twins accordingly wear halves of eggshells as hats and they are identified by them in the iconography as they flank a goddess (Helen) or her symbol (see, e.g., Chapouthier 1935). They are also connected with the morning and evening stars and with horses. In one story they rescue Helen after she has been abducted. One can see here the importance of a young goddess and something of the role of her twin brothers in supporting her. Her brothers play a part when suitors come from far and wide to woo Helen, and she is won by Menelaus who becomes king of Sparta by this match. Helen's mother Leda was the queen of Sparta before Helen. Menelaus married in to the royal house of Sparta.

The most striking example in Ancient Greece of a hero who comes from afar and gains a kingdom by marrying the princess, is the story of Pelops. Oenomaus, king of Pisa, challenges any suitor for the hand of his daughter, Hippodamia, to a chariot race. In the past, all the suitors have been defeated and Oenomaus has placed their heads on spikes on his palace wall but Pelops is undaunted. He wins the chariot race and becomes king through his marriage. I am sure this resonates 
with many folk-narrative scholars as the happy ending of a fairy-tale. In a sixteenth-century version of a Scottish ballad called "Sir Colin" the young hero takes on a three-headed giant who has stolen the king's cup at a feast, after the king has promised that whoever fetches his cup back "sall haue my dochtar deir/ and all efter my day." (Stewart 1972). Maybe some of this - not the three-headed giant but the means of gaining a kingdom - had a stronger hold on fact than is sometimes thought, if we go far enough back into the past.

I am sure that scholars have often been haunted by the feeling that similar story lines known to them descended from half-apprehended myths, but it has been difficult to confirm or deny the existence of patterns that have been glimpsed in this way. I think the situation has now changed in two ways. One change is the introduction of the analogical discovery method which gives us a means of articulating and communicating ideas in a manner that takes suggestions out of the realm of the subjective. The second change is the realisation that the concepts arrived at through the study of narratives are not confined to the narrative plane but are part of a posited total cosmology that can be approached intellectually from a variety of different directions.

\section{References}

Bek-Pedersen, Karen 2006. Interpretations of Ynglingasaga and the Mabinogi: Some Norse-Celtic correspondences. Anders Andrén, Kristina Jennbert and Catharina Raudvere (eds.). Old Norse religion in long-term perspectives. An international conference in Lund, Sweden, June 3-7, 2004. Lund: Nordic Academic Press, pp. 331-335.

Chapouthier, F. 1935. Les Dioscures au service d'une déesse. Paris: E. de Boccard.

Coe, Michael D. 1992. Breaking the Maya Code. London: Thames and Hudson.

Dumézil, Georges 1973. The Destiny of a King. Chicago and London: University of Chicago Press.

Fauconnier, Gilles 2001. Conceptual Blending and Analogy. Dedre Gentner, Keith J. Holyoak \& Boicho N. Kokinov (eds.). The Analogical Mind: Perspectives from Cognitive Science. Cambridge, MA, and London: MIT Press, pp. 255-285.

Finkelberg, Margalit 2005. Greeks and Pre-Greeks: Perspectives on Aegean Prehistory. Cambridge: Cambridge University Press.

Gentner, Dedre 1983. Structure-Mapping: A Theoretical Framework for Analogy. Cognitive Science, 7, pp. 155-170.

Gentner, Dedre and Michael Jeziorski 1993. The shift from metaphor to analogy in

Western science. Andrew Ortony (ed.). Metaphor and Thought. 2nd edn. Cambridge:

Cambridge University Press, pp. 447-480.

Greimas, A. J. 1992. Of Gods and Men. Bloomington: Indiana University Press.

Griffiths, J. Gwyn (ed.) 1970. Plutarch's "De Iside et Osiride”. Cardiff: University of Wales Press.

Helms, Mary W. 1998. Access to Origins: Affines, Ancestors and Aristocrats. Austin: Texas University Press.

Jones, Gwyn \& Thomas Jones (tr.) 1949. The Mabinogion. London: J. M. Dent.

Lincoln, Bruce 1986. Myth, Cosmos, and Society: Indo-European Themes of Creation and Destruction. Cambridge, MA \& London: Harvard University Press. 
Lord, Albert B. 1978. Foreword. David E. Bynum. The Daemon in the Wood: A Study of Oral Narrative Patterns. Cambridge, MA: Harvard University Press, pp. xvii-xviii.

McCone, Kim 1990. Pagan Past and Christian Present in Early Irish Literature. Maynooth: An Sagart.

Stewart, Marion 1972. A Recently-Discovered Manuscript: 'ane taill of Sir coiling ye knyt. Scottish Studies, 16, pp. 23-39.

Ward, Donald 1968. The Divine Twins: An Indo-European Myth in Germanic Tradition. Berkeley and Los Angeles: University of California Press.

West, M. L. 1975. Immortal Helen: An Inaugural Lecture. London: Bedford College, University of London.

Winn, Shan M. M. 1995. Heaven, Heroes, and Happiness: The Indo-European Roots of Western Ideology. Lanham \& New York \& London: University Press of America. 